\title{
THE YELLOW LADY'S-SLIPPER VARIETIES IN SASKATCHEWAN AND WESTERN CANADA
}

VERNON L. HARMS, The W.P. Fraser Herbarium, University of Saskatchewan, Saskatoon, Saskatchewan. S7N OWO

Yellow Lady's-slippers are one of the more frequently encountered, familiar and attractive of Saskatchewan's larger native orchids in the southern half of the province. Unfortunately, there has been some confusion concerning the recognition and respective occurrences of the Large versus the Small Yellow lady'sslippers in Saskatchewan and Western Canada.

Formerly the Small Yellow Lady'sslipper in North America was recognised as Cypripedium parviflorum Salisb. and considered specifically distinct from the Large Yellow Lady's-slipper, $C$. pubescens Willd. Today, together with the more eastern C. planipetala (Fern.) Morris \& Eames, as well as the Eurasian C. calceolus L. s. str., these are usually recognised as separate varieties of a single widespread species, for which the Linnaean name, $C$. calceolus, then becomes applicable according to priority rules. Under this concept, $C$. calceolus var. parviflorum (Salisb.) Fern. becomes the name for the Small Yellow Lady'sslipper, while C. calceolus var. pubescens (Willd.) Correll applies to the Large Yellow Lady's-slipper.

Some taxonomic confusion has been apparent involving the recognition and names of the two latter varieties, at least with respect to Saskatchewan and Western Canada. This can be attributed to a combination of the following reasons:

(1) sometimes authors of taxonomic references have not distinguished any taxonomic varieties within the broadly accepted species C. calceolus; ${ }^{8} 1323$

(2) frequently all North American populations have been accepted together as only a single variety, but this separate from the Eurasian var. calceolus, with the epithet pubescens, ascribed to the total spectrum of North American populations1 571122 (such usages by Breitung ${ }^{5}$ and Moss ${ }^{22}$ for Saskatchewan and Alberta, respectively have sometimes been misinterpreted as referring to the Large Yellow Lady's-slipper - e.g. Scoggan's erroneous citation of Breitung 5 as the supposed basis for the distribution of var. pubescens s. str. in Saskatchewan) ${ }^{27}$

(3) the apparently erroneous attribution (reversal?), at least with respect to Western Canada, of the mapped geographical ranges of these two varieties in Luer's popular modern treatise on North American native orchids. ${ }^{18}$

\section{Identification}

The most consistent and useful criteria for separating the Small and Large varieties, based on the literature $9 \quad 1118$ 212627 as well as on personal field and herbarium experiences, are presented in the following identification key (see fig. 1 for depiction of terminology used for floral and vegetative characters). 

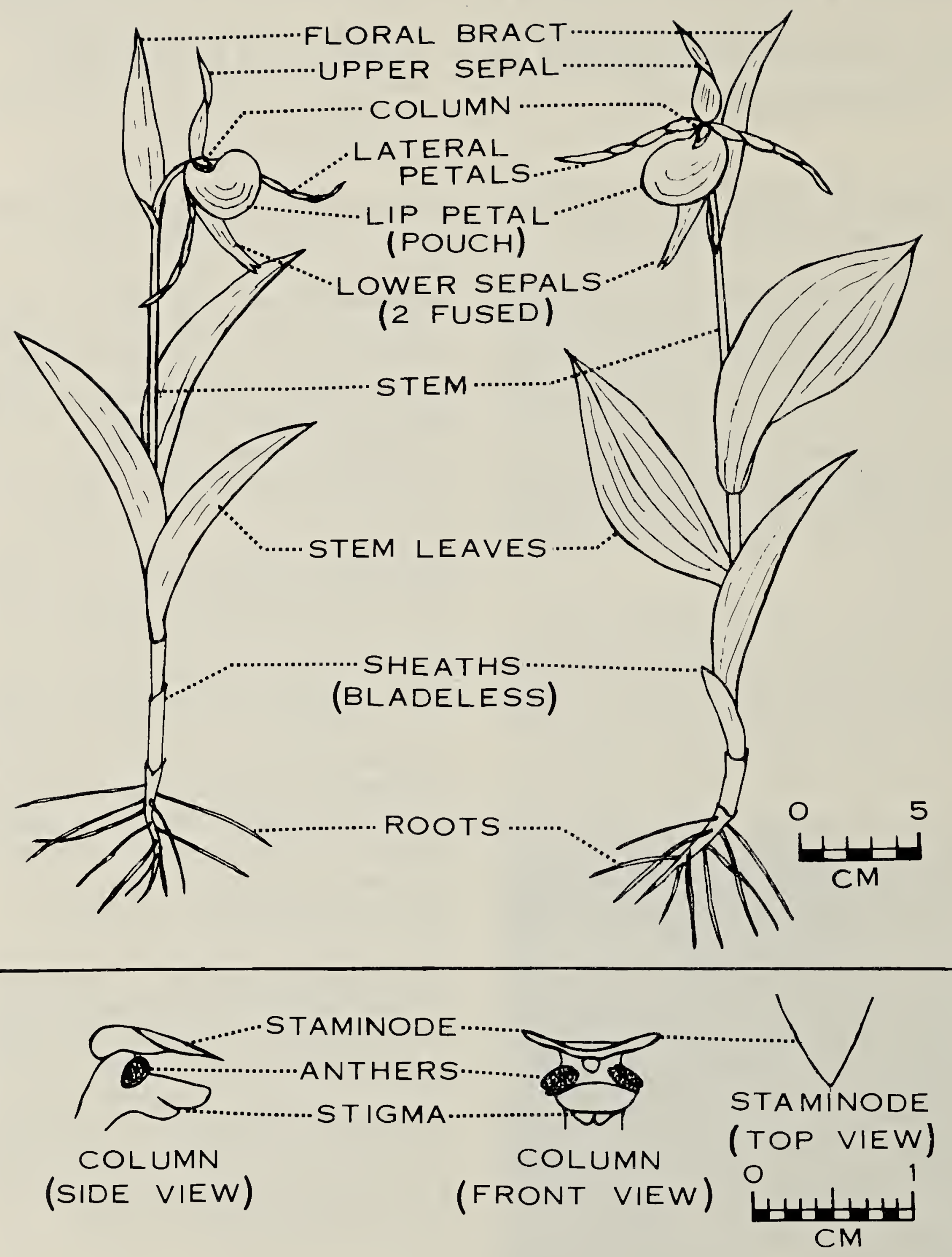

Figure 1. Floral and vegetative characteristics of Yellow Lad'y's- slippers, Cypripedium calceolus 
1a Lip-pouch (1.5-) 2-3 (-4) cm long, 1-2 (-2.5) cm broad, mostly bright yellow; sepals 2-4 (5) $\mathrm{cm}$ long, they and the lateral petals mostly brownish or purplish; darker than the next; lateral petals $3-5 \mathrm{~cm}$ long; plants to $4(-5) \mathrm{dm}$ all, with $3-4$ (-5) stem leaves, the largest stem leaves 2-6 (-8) cm wide; staminode about $8 \mathrm{~mm}$ long; fresh flowers distinctly fragrant

Ib Lip-pouch 3-5 (-7) cm long, 2-4 cm broad, mostly paler yellow; sepals (3-) 4-7 $(-8) \mathrm{cm}$ long, they and the lateral petals usually paler and yellowish-green; lateral petals (4-) 5-7 (-9) cm long; plants to $7 \mathrm{dm}$ tall, with 4-6 stem leaves, the largest stem leaves $4-10(-12) \mathrm{cm}$ wide; staminode about $11 \mathrm{~mm}$ long; fresh flowers only indistinctly fragrant.

Since some of the key characters are overlapping to a degree, they need to be used in combination rather than stressed singly. Such is hardly unusual or unexpected when distinguishing varieties; in fact, if the character-distinctions were consistently sharp and unequivocal, the respective groups would be better recognised as separate species. Of the above key characters, leaf width and plant height seem especially plastic ones subject to environmental modification, and as a result only toward their upper extremes are they helpful in distinguishing plants of var. pubescens (i.e. smaller and narrower leaved specimens should not be excluded from the latter variety on these bases alone). The floral part measurements are those for mature flowering stages, the numbers in parentheses representing unusual extremes.

\section{Distribution}

The Small Yellow Lady's-slipper is relatively widespread throughout much of the southern half of Saskatchewan, except in the southwestern drier Short-grass Prairie Zone. It is characteristic of moist shore-woods and spring-fed wooded ravines in the Grassland and Aspen Parkland zones, and of the above habitats, plus other wet woods and bog/fen habitats, across the Southern Boreal Forest (Mixed-wood) zone. Only in Aspen Parkland and the deciduouswooded Qu'Appelle Valley does it appear to be fairly frequent. Elsewhere, col- onies seem rather uncommon to even rare. It remains inrecorded in Saskatchewan from the Northern Boreal Forest zone or on the Canadian Precambrian Shield. The map of figure $2 \mathrm{a}$ shows the voucher-documented distribution of the Small Yellow Lady's-slipper in Saskatchewan, and that of Figure $3 \mathrm{a}$ its known range throughout Western Canada and the immediately adjacent United States, with information on the non- Saskatchewan distributions of the latter based on various literatures sources. ${ }^{15} 20232426$ 2728 The locality dots on the Saskatchewan distribution map (Fig. 2a) are based only on verified herbarium specimens (in SASK, USAS, FGH, DFH, SCS, DAO, and (AN), so the apparent gaps could merely represent artifacts of collecting that readers may help to fill in with localities known to them. It should be noted that for plants, sight reports alone, lacking documentation by voucher specimens filed in a recognised herbarium, are always regarded as unverified records. A recent significant range extension for the province was Ledingham's report of this orchid from the Saskatchewan Cypress Hills, where it was previously unrecorded. ${ }^{16} 46 \quad 1013$ The transcontinental var. parviflorum ranges westward from Saskatchewan to the upper Fraser River Valley, British Columbia, and northwestward to northwestern British Columbia to Great Bear Lake and the MacKenzie River in the Northwest Territories to the Ogilvie Mountains (north of Dawson) in Yukon 


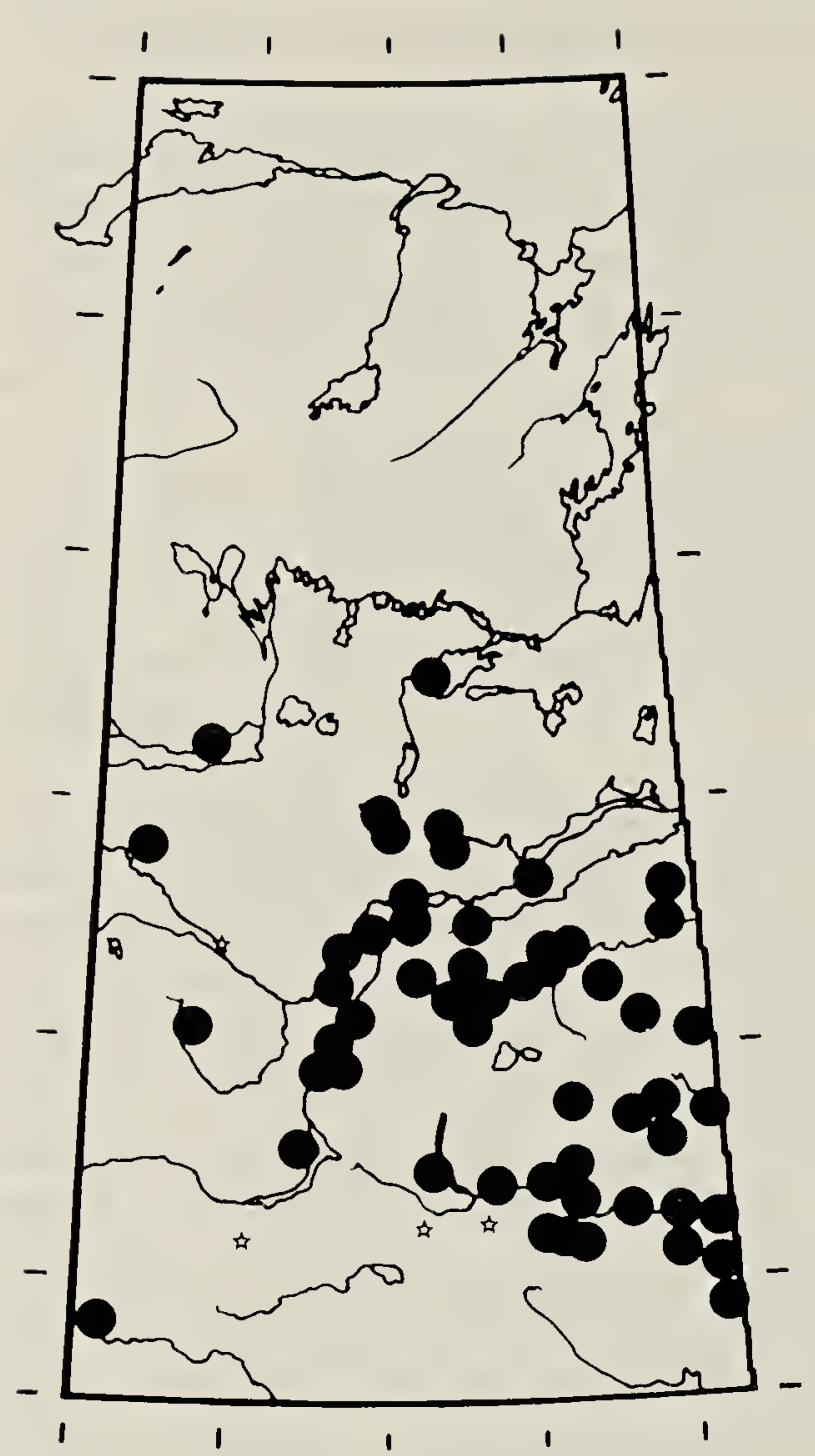

A. var. PARVIFLORUM

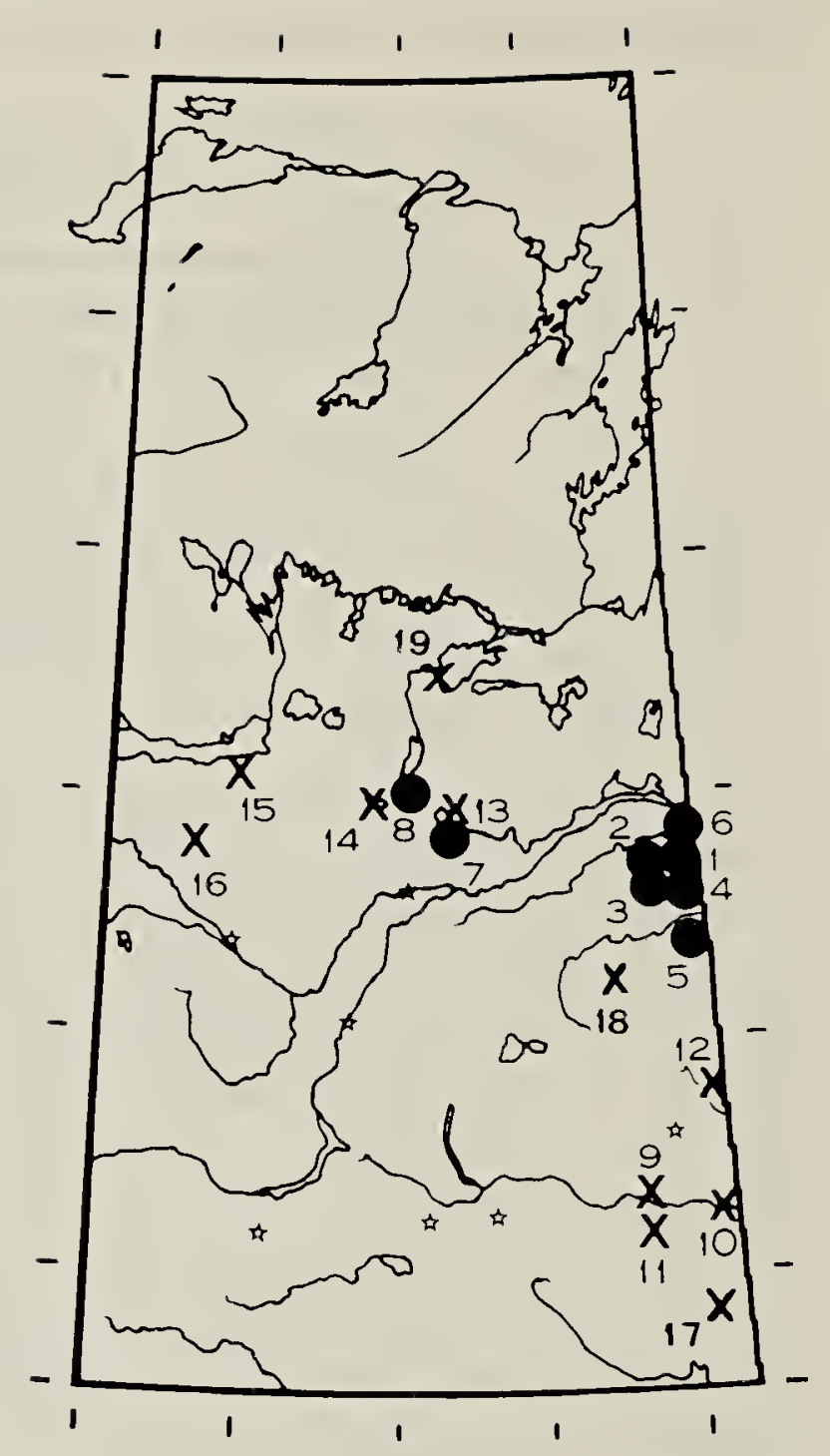

B. var. PUBESCENS and intermediates

Figure 2. The recorded (voucher documented) distributions of the varieties of Yellow Lady'sslippers in Saskatchewan: a. Small Yellow Lady's-slipper, Cypripedium calceolus var. parviflorum (solid circles). b. Large Yellow Lady's-slipper, C. c. var. pubescens (solid circles), and purported varietal intermediates $(X)$. Numbers on map correspond to the collection localities as cited in the text.

Territory and to the Bettles River on the south slope of the Brooks Range in Alaska. ${ }^{15} 24812$ Breitung suggested that, if segregated, the Saskatchewan plants of this species would belong to var. parviflorum. ${ }^{5}$ Boivin concurred by recognising only the Small Yellow Lady's-slipper (C.c. var. parviflorum) in Saskatchewan and westward, indicating that the more eastern var. pubescens extended to only as far west as southern Manitoba. ${ }^{2} 3$ This conclusion appears to have been justified at that time based on those specimens in SASK and USAS personally annotated by B. Boivin in 1957, and by the pre-1979 collections represented in Ottawa herbaria (DAO \& CAN), as verified by the present author.

The Large Yellow Lady's-slipper, C. C. var. pubescens, has subsequently been documented for Saskatchewan where it has been collected in the Pasquia Hills (De Vries, B., pers. corr.), the Porcupine Hills and Carrot River Valley, and near Montreal and Candle Lakes (Clark, J., pers. comm.). 14

The relatively few collections substantiating the locality records for the Large Yellow Lady's slipper in Saskatchewan are briefly listed below, along with dates, 
collectors, collecting numbers and herbaria where filed. (The herbarium acronyms mostly follow international usage: $\mathrm{SASK}=$ Fraser Herbarium, University of Saskatchewan, USAS = University of Regina, SCS = Swift Current Canada Agriculture Station, $\mathrm{FQH}=$ Fort $\mathrm{Qu} \mathrm{A}^{\prime} \mathrm{Ap}$ pelle Herbarium, DFH $=$ Donald $F$. Hooper's private herbarium, DAO = Biosystematics Research Institute, Canada Agriculture, Ottawa and CAN = National Museum of Canada.) The numbers in the list below correspond directly to the numbered localities on the Saskatchewan distribution map (Fig. 2b).

The large Yellow Lady's-slipper, reportedly, is characteristic of drier fresh or mesic woodlands rather than moist to wet woods, shores and bog/fen habitats as is the Small Yellow Lady's-sipper. While this supposed habitat distinction seems somewhat upheld by Saskatchewan collections, it hardly represents a clear separation, partly because the Small Yellow Lady's-slipper occupies such a broad moisture spectrum here by occurring often in fresh-mesic shore woods as well as in wetter habitats.

The maps show the voucherdocumented distribution of the Large
Yellow Lady's- slipper in Saskatchewan (Fig. 2b), and its known range throughout Western Canada and the immediately adjacent United States (Fig. 3b); the nonSaskatchewan distributions of the latter are based on a variety of literature references. ${ }^{20} 26 \quad 2728$

At least some intermediate plants, if not even a general zone of intergradation, might be expected between any varieties of the same species where their ranges meet or coincide. The apparent "hybrids" (i.e. intermediates) between the varieties parviflorum and pubescens, identified by the author for Saskatchewan, are indicated by an $X$ on the Saskatchewan and Western Canada distribution maps for var. pubescens (figures $2 b$ and $3 b$ ). Those specimens identified as varietal 'intermediates' revealed some but not all flower characters distinctly within the morphological range for var. pubescens. The collection localities for the accepted "intermediates" (other than at sites where they occurred together with "good" var. pubescens) are listed below, numbered here to correspond to the numbered localities mapped (Fig. 2b).

\section{SASKATCHEWAN RECORDS OF THE LARGE YELLOW LADY'S-SLIPPER}

Pasquia Hills:

1. Otosquen Road, 26 June 1974, B. De Vries 3017.74 (FQH)

2. Rice River, 26 June 1974, B. De Vries 3018.74 (FQH)

3. Fir River Road, w of Mile 13, 7 July 1981, V.L. Harms, D.F. Hooper, P. Sky \& L. Baker 29,410 (SASK, DFH)

4. Chemong Creek along Chemong Siding Road, 8 July 1981, V.L. Harms, D.F. Hooper, P. Sky \& L. Baker 29,487 (SASK.) Porcupine Hills:

5. N Armit River, 6 km w-sw of Armit, 27 June 1983, V.L. Harms, D.F. Hooper \& L. Baker 31,910 (SASK, DFH) Carrot River Valley:

6. E of Murphy Lake near Sask.-Man. border, 21 July 1984, V.L. Harms, D.F. Hooper \& L. Baker 33,148A (SASK) Central (Southern Boreal )Saskatchewan:

7. Candle Lake, $3 \mathrm{~km} \mathrm{~s}, 29$ June 1983, Joyce \& Russel Clark 107 (SASK)

8. Nikek Lake, s of Montreal Lake, 20 June 1982, Joyce Olsen \& Russel Clark 102 (SASK) 


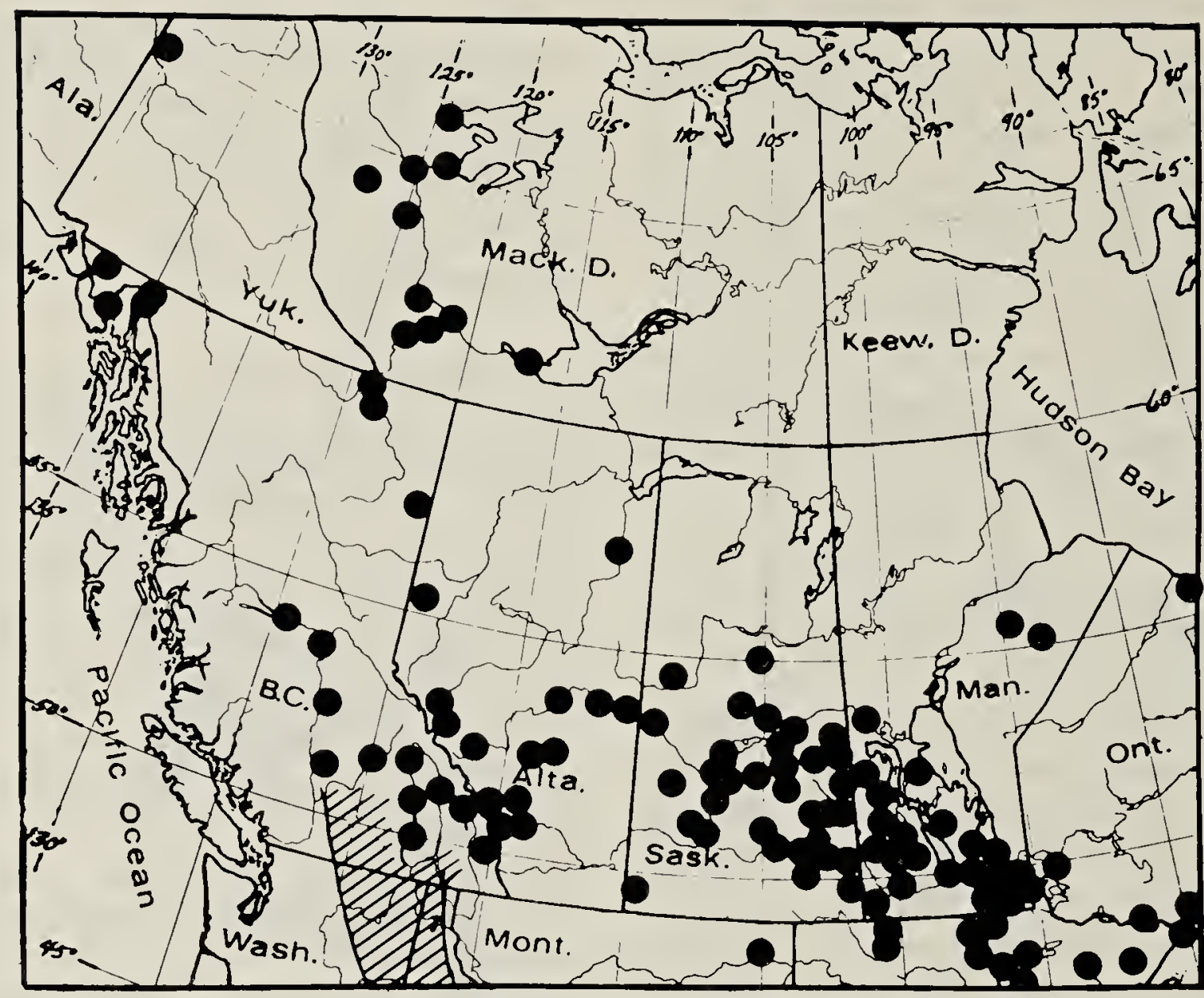

A. var. PARVIFLORUM

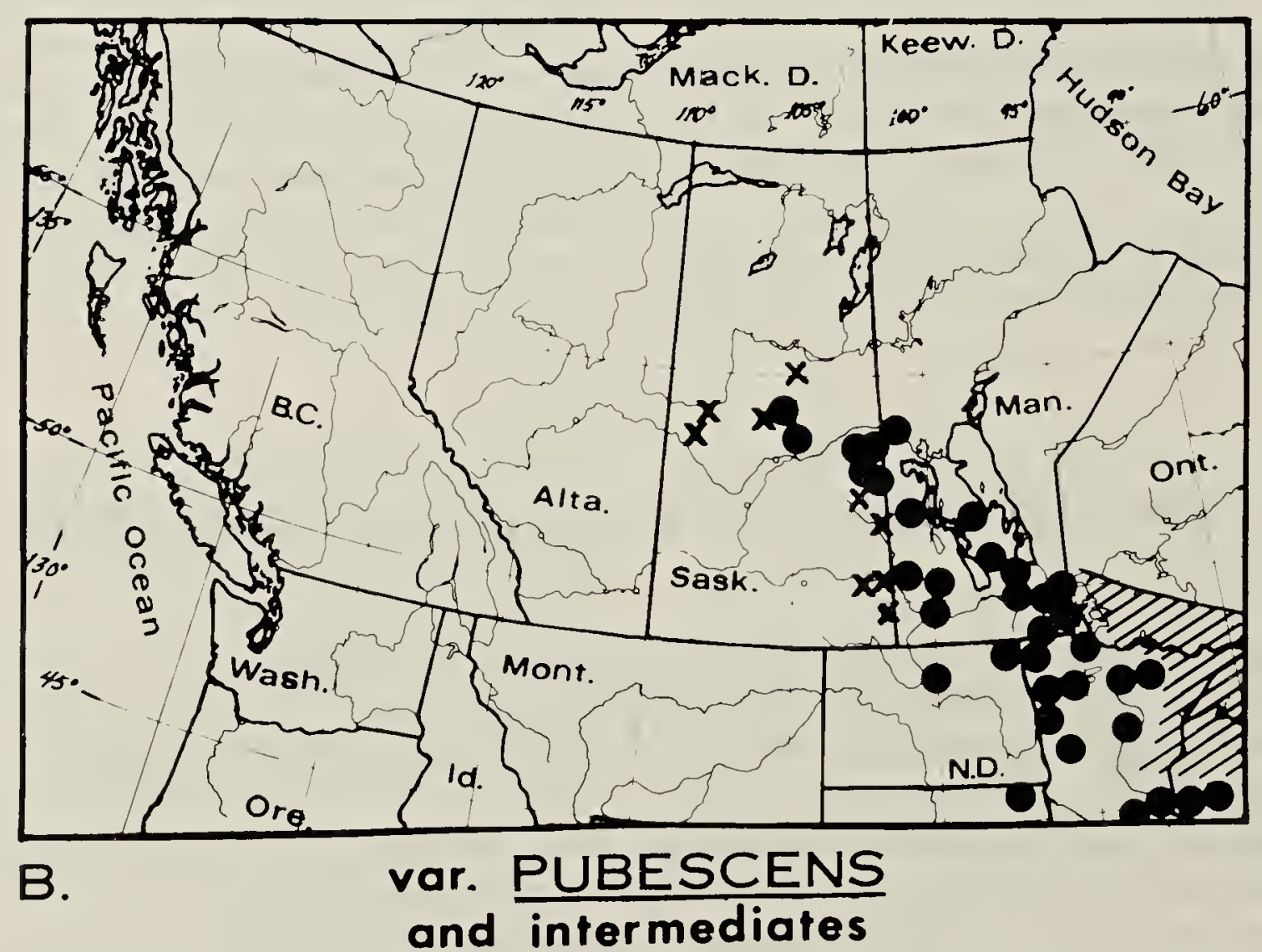

Figure 3. The recorded distribution of the Yellow Lady's-slipper varieties in western Canada and the adjacent United States: a. Small Yellow Lady's-slipper, Cypripedium calceolus var. parviflorum (solid circles). b. Large Yellow Lady's-slipper, C. c. var. pubescens (solid circles) and, for Saskatchewan only, the purported varietal intermediates $(X)$. Hatched areas on the maps indicate general geographical ranges reported in the literature for which more precise information for locality dots was unavailable. 
The distributional pattern formed by the recorded, Saskatchewan localities of the Large Yellow Lady's Slipper (see figs. $2 \mathrm{~b}, 3 \mathrm{~b})$ corresponds to the apparent 'migration route' of various other eastern species, subspecies and varieties that reach their northwesternmost extent in the series of uplands - viz. Riding Mountain (in Manitoba), Duck Mountain, Porcupine Hills, Pasquia Hills and Bug Hills - that together comprise the Manitoba Escarpment (= Prairie Coteau sensu Boivin ${ }^{3}$ ), bordering the southwestern shores of the former postglacial Lake Agassiz. The expanded distributional pattern in Saskatchewan formed by adding the localities of our recognized varietal "intermediates" to those of the "good" var. pubescens (see figs. 2b, 3b), reveals the not overly surprising picture of a westward extension of the Large Yellow Lady's- slipper's influence, if not actually verified presence in "pure form" along the Assiniboine, Qu'Appelle and Pipestone River valleys, as well as along the Manitoba Escarpment Uplands. It extends westward from the latter nearly across the province, to Prince Albert National Park, Brightsand Lake, and Meadow Lake. The latter, more western Saskatchewan stations in the Southern Boreal Forest Zone may at first glance seem "out of scope." But interestingly these all fall within the narrow belt of the postulated maximum northwestward extension of the eastern deciduous forest into Saskatchewan along the south side of the former post-glacial Lake Agassiz and westward essentially across the province during the earlier moister part of

\section{SASKATCHEWAN COLLECTIONS INTERMEDIATE BETWEEN THE SMALL AND LARGE YELLOW LADY'S-SLIPPER VARIETIES}

Qu'Appelle River Valley and south:

9. Stockholm, 4 mi. s; 24 June 1954, G.W. Selleck 63 (SASK)

10. Qu'Appelle River, 7.5 mi. n of Rocanville, 17 June 1971, N.A. Skoglund 492A (SASK) 11.

Pipestone River Valley, 10 mi. s of Broadview, 18 June 1964, G.F. Ledingham, Roney and Zacharius 3774 (USAS)

17. Wawota, 13 mi. se, July 1983, Kay Kennet s.n. (in part) (SASK 76158) East-Central Saskatchewan:

18. Carragana, 5.5 km w, 26 June 1983, V.L. Harms \& L. Baker (31,830 SASK) Duck Mountain:

12. Madge Lake, Duck Mountain Prov. Park, 20 June 1973, V.L. Harms 19,771 (SASK). A sight record from this locality by B. de Vries 15 July 1982 would possibly have belonged here (De Vries, B., pers. corr.). Central (Southern Boreal) Saskatchewan:

13. Candle Lake, 2 July 1963, J.K. Jeglum 668-63 (SASK 39487)

14. Prince Albert National Park, 21 June 1941, W.P. Fraser s.n. (SASK 7287-A)

19. Lac La Ronge, 1 July 1948, G.W. Ledingham 48-417-b (in part) (USAS) WestCentral (Southern Boreal) Saskatchewan:

15. Meadow Lake, 6-7-54, Wm. MacNeill S5405 (SASK)

16. Brightsand Lake, 26 June 1956. Robert Connell s.n. (SASK 26715 \& 26716) 
the post-Wisconsin "Hypsithermal (or Climatic Optimum) Period" about 8000-6000 years ago. ${ }^{17} 25$

The closely adjacent Manitoba records, as well as our Saskatchewan "intermediate specimens," suggest that the Large Yellow Lady's-slipper might be expected and should be looked for, at least in the lower Qu'Appelle, Pipestone and Assiniboine River Valleys, and in the Duck Mountain Provincial Park regions of easternmost Saskatchewan. It should also be looked for westward across the southernmost part of the Southern (Mixed-wood) Boreal Forest and northern Aspen Parkland zones.

The Large Yellow Lady's-slipper, if taxonomically segregated, unquestionably deserves a rare plant status for Saskatchewan, while the Small Yellow Lady'sslipper would not so qualify under the usual criteria for such designation within a province because it is both too widespread and often occurs in sizeable local colonies. ${ }^{19}$ Nonetheless, on a continental scale, the Yellow Lady's-slipper (often with varieties not distinguished) has been accorded a rare plant status in most other provinces and states, and is also protected by the Convention on the international Trade of Endangered species (CITES). ${ }^{1}$

\section{Acknowledgements}

Numerous persons over the years have cumulatively added to our knowledge concerning the Yellow Lady's-slipper orchids in Saskatchewan. Deserving special acknowledgement have been the notable contributions during the last dozen years of the following individuals: Joyce and Russel Clark, Bernard de Vries, Donald F. Hooper, Kristal Kennett, George F. Ledingham and N. Andy Skoglund.

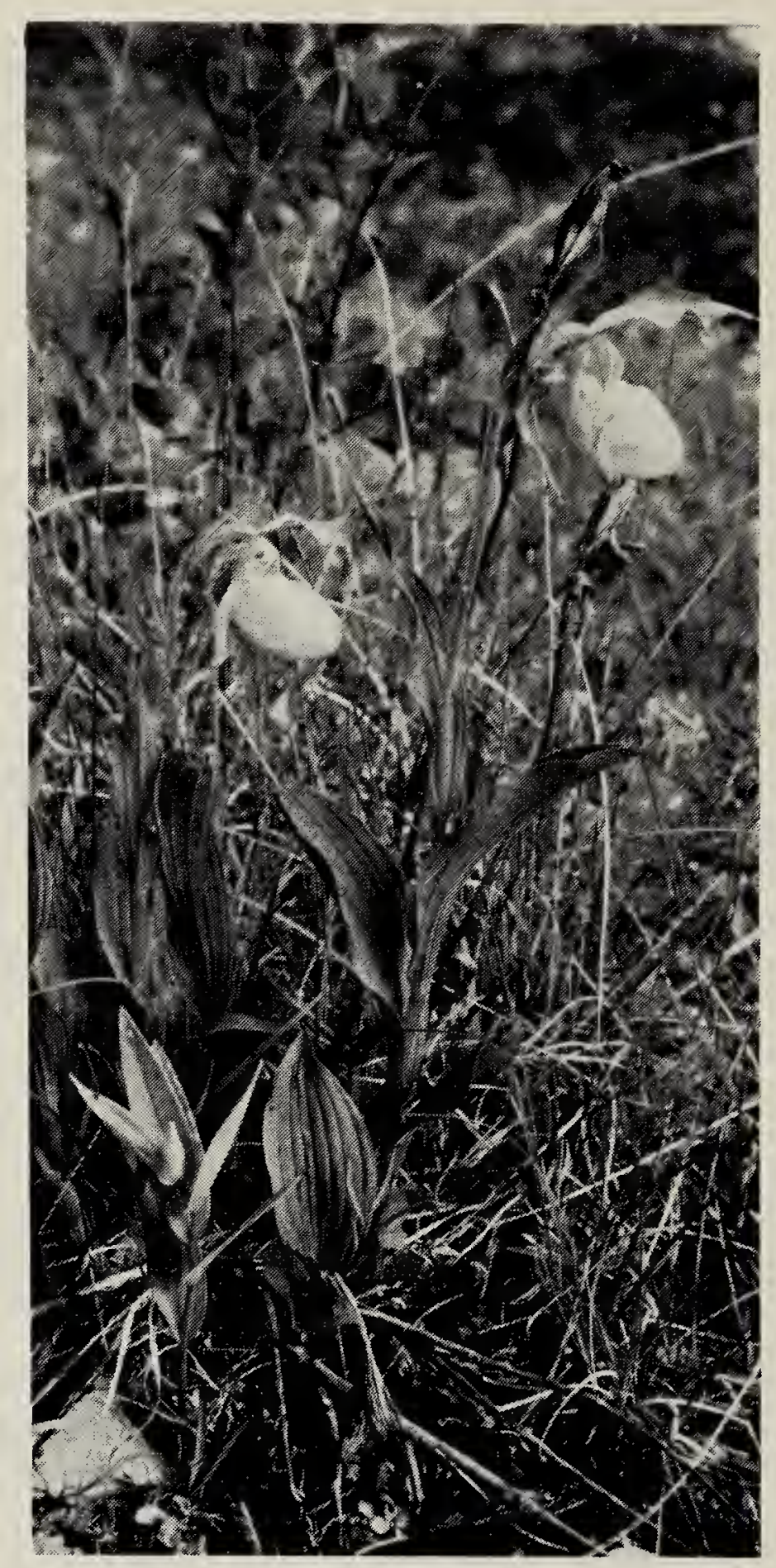

Large Yellow Lady's-slipper

Wayne Harris

1 ARGUS, G.W. 1978. List of Canadian flora affected by CITES. CITES Report No. 4, Canadian Wildl. Serv., Environment Canada. 14 pp.

2 BOIVIN, B. 1967. Enumeration des Plantes du Canada. Le Naturaliste Canadien Vol. 94:145. 
${ }^{3}$ BOIVIN, B. 1979. Flora of the Prairie Provinces. Part IV. Provancheria 5, Univ. Laval, Quebec City, P. Q.

${ }^{4}$ BREITUNG, A.J. 1954. A botanical survey of the Cypress Hills. Can. Field-Nat. 68:55-92.

${ }^{5}$ BREITUNG, A.J. 1957. Annotated catalogue of the vascular flora of Saskatchewan. The Am. Midland Nat. 58(1):1-72.

${ }^{6}$ CORMACK, R.G.H. 1948. The orchids of the Cypress Hills. Can. Field- Nat. 62:155-156.

${ }^{7}$ CORRELL, D.S. 1950. Native orchids of North America. Chronica Botanica, Waltham, Mass. 399 pp.

8 DOUGLAS, G.W., G.W. ARGUS, H.L. DICKSON and D.F. BRUNTON. 1981. The rare vascular plants of the Yukon. Syllogeus no. 28, Nat. Mus. Can., Ottawa. 61pp + maps.

9 FERNALD, M.L. 1950. Gray's Manual of Botany, Eighth Edition. Amer. Book Co.

10 FISHER, R.M. 1980. The orchids of the Cypress Hills. O. Pall, Calgary. 44 pp.

"GLEASON, H.A. and A. CRONQUIST. 1963. Manual of vascular plants of northeastern United States and adjacent Canada. D. Van Nostrand Co., N.Y.

12 HARMS, V.L. 1973. New record for the Yellow Lady's-slipper Orchid, Cypripedium calceolus L. subsp. parviflorum (Salisb.) Hult., from Alaska. Rhodora 75(803):491.

13 HARMS, V.L. 1974. The native lady's-slipper orchids of Saskatchewan. Blue Jay 32(2):69-74.

${ }^{14}$ HOOPER, D.F. 1982. Rare plants found near Hudson Bay, Saskatchewan. Blue Jay 40(2):69-72.

15 HULTEN, E. 1968. Flora of Alaska and neighboring territories. Stanford Univ. Press. Stanford, Calif.
16 LEDINGHAM, G.F. 1981. Book review: The Orchids of the Cypress Hills by R.M. FISHER. Blue Jay 39(4):246.

17 LOVE, D. 1959. The postglacial development of the flora of Manitoba: a discussion. Can. J. Bot. 37:547-585.

18 LUER, C.A. 1975. The native orchids of the United States and Canada (excluding Florida). The New York Bot. Garden, N.Y.

${ }^{19}$ MAHER, R.V., G.W. ARGUS, V.L. HARMS and J.H. HUDSON. 1979. The rare vascular plants of Saskatchewan. Syllogeus no. 20, Nat. Mus. of Nat. Sci., Ottawa. 55 pp. + maps

20 MCGREGOR, R.L., W.T. BARKLEY, et al. 1977. Atlas of the flora of the Great Plains. lowa State Univ. Press, Ames, Iowa.

21 MOHLENBROCK, R.H. 1970. The illustrated flora of Illinois. Flowering plants - lilies to orchids. Southern Ill. Univ. Press, Carbondale.

22 MOSS, E.H. 1959. Flora of Alberta, Edition 1. Univ. Toronto Press, Toronto.

23 PACKER, J.G. 1983. Flora of Alberta, Edition 2. Univ. Toronto Press, Toronto.

24 PORSILD, A.E. and W.J. CODY. 1980. Vascular plants of continental Northwest Territories. Nat. Mus. Can., Ottawa.

25 RITCHIE, J.C. 1976. The Late-Quaternary vegetational history of the western interior of Canada. Can. J. Bot. 54:1793-1818.

26 SCOGGAN, H.J. 1957. Flora of Manitoba. Nat. Mus. of Can. Bull no. 140, Ottawa.

27 SCOGGAN, H.J. 1978. Flora of Canada, Part 2:Pteridophyta, Gymnospermae, Monocotyledonae. Nat. Mus. Can., Ottawa. Publ. in Bot. no. 7.

${ }^{28}$ SMITH, T. Ed. n.d. Continuation of the study of native orchids (in Manitoba). The Orchidian, The Can. Orchid Soc., Vaol 1, no. 3:4-10. 